\title{
State Building and Peace Building in Bosnia And Herzegovina: Explaining the Uncertain Path to EU MEMbership
}

\author{
Jordi MARTÍN-Díaz, Barcelona*
}

\section{Content}

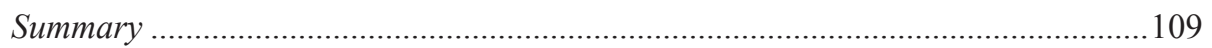

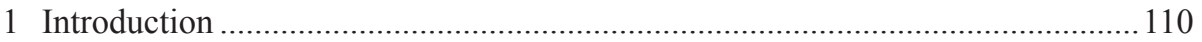

2 The evolution of the international intervention in Bosnia and Herzegovina ........ 111

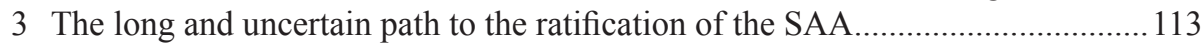

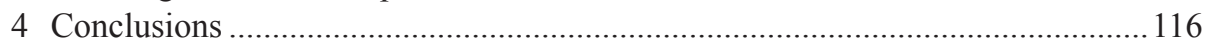

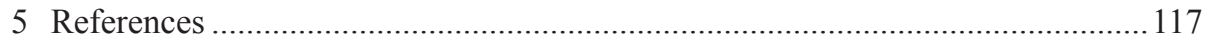

\section{Summary}

The European Union (EU) enlargement, which reinforces peace, democracy and stability in Europe, has been a central foreign policy tool for the promotion of the domestic reforms required in candidate countries. However, the EU's intervention has been far from effective in the post-war context of Bosnia and Herzegovina, which conflict ended after three-and-a-half years with the signature of the Dayton Peace Agreement (DPA) in December 1995. The Agreement was considered one of the most ambitious peace-building projects, defining in most of its annexes the political project of state building and societal reconstruction of Bosnia. The goal was thus ending war and setting the framework to create a viable and self-sustained state. The mission was coordinated by the Office of the High Representative, set as the ad hoc body responsible for supervising and coordinating the civil aspects of the DPA. Empowered in 1997 in order to push for the implementation of the peace agreement and assuring

* Jordi Martín-Díaz, PhD., Department of Human Geography Montalegre 6, Office 3008, University of Barcelona, Barcelona, Spain; email: jordi.martin@ub.edu 
its compliance, the High Representative's powers were gradually replaced by the pull of European Institutions. The European path of Bosnia and Herzegovina reached its climax with the signature of the Stabilization and Association Agreement in 2008. Dealing with the challenges of the state-building and peace-building processes in Bosnia and Herzegovina, the aim of this paper is to analyse the limited progresses of Bosnia in the complex advance towards the European accession despite the lingered international intervention. The paper is structured in two sections. The first one analyses the evolution of the international intervention in the country. The second section focuses on the long process of ratifying the Stabilisation and Association Agreement, which have been compromising the European path of Bosnia.

\section{Introduction}

The power of attraction of European Union (EU) membership has been hailed as one of the most powerful tools of EU foreign policy. Enlargement, seen as reinforcing peace, democracy and stability in Europe, serves as a key driver for political and economic reform in candidate countries (Juncos 2012). However, the process of enlargement is very demanding in Western Balkans because of the legacy of war. This is especially evident in the case of Bosnia and Herzegovina where despite the massive international intervention during the post-war period, limited success has been achieved in the construction of a functional state and the implementation of the Dayton Peace Agreement. Despite the evolution of reforms has been uneven along the post-war period, since the pull of the European integration in mid-2000s the political situation has become increasingly complex, halting the long journey towards the European integration since 2008.

In Bosnia, the integration within the European Union could become a particularly effective tool to advance in the necessary reforms to make a functional state while overcoming the divisive agenda in the country among the elites of the three constitutive ethno-national groups; these are the Bosnian Muslims or Bosniaks, Bosnian Croats and Bosnian Serbs. Despite having signed the Stabilisation and Association Agreement (SAA) in 2008, it has not been put into force for almost seven years since preconditions set by Brussels were not continuously met due to the incapability to reach consensus among political parties.

Structured in two sections, this paper focuses on the complexity of the European path of Bosnia and Herzegovina. The first section analyses the evolution of the international intervention in relation to the implementation of the Dayton Peace Agreement. It shows that the challenges in the country emerged since the beginning of the implementation of peace accords and have been hardly overcome despite the empowerment of the High Representative (HR). In the second section the focus is on the long path towards the signature of the SAA. The goal of this second section is two- 
fold, highlighting both the political regression experienced in the country since the first serious attempt to reform the constitution in 2006 and the internal contradictions of the EU's enlargement process while being implemented in the post-war context of Bosnia and Herzegovina. At the end, the progress to unblock the ratification of the SAA is presented.

\section{The evolution of the international intervention in Bosnia and Herzegovina}

The Dayton Peace Agreement (DPA) was signed after three weeks of negotiations. It was not a conventional peace agreement since ten out of twelve annexes were not military. Despite not having the same concretion that the two military annexes, the civilian ones set the framework to rebuild the country both socially and economically after three and a half years of war. In these annexes, the Constitution of Bosnia and Herzegovina was included and also the territorial division in two autonomous entities, the Federation of Bosnia and Herzegovina [Federacija Bosne i Hercegovine, $\mathrm{FBiH}$ ] and the Republika Srpska (RS), or the right of refugees and Internally Displaced Persons (IDP's) to return to pre-war homes.

In its annex 10, the DPA set the High Representative (HR) as the responsible to monitor the implementation of the peace settlement. The Office of the High Representative became thus the ad-hoc body responsible for supervising and coordinating the civilian aspects of the DPA. Yet, the peace building had to advance in a parallel way to the state-building process. In this sense, according to the accords, peace would be achieved once Bosnian statehood was consolidated and a minimum of consensus was achieved among all ethnic communities regarding the legitimacy of the Bosnian state (DonAIs 2005). In practice, the state-building process that should create a functioning state through the development of joint institutions was challenged from the very beginning.

The politics of ethnic conflict in Bosnia continued during most of the post-war period in part due to the fact that the three ethno-national parties that fought the war kept controlling the political arena. It had a negative impact on the adoption of reforms promoted by the international community, which aimed at creating a market democracy. In this sense, the reforms promoted by international actors in the framework of the DPA weakened the very foundation of the power achieved by ethno-national parties during the war, with ethnic territorialisation as one of the main practices. In other words, both the development of the state institutions and the implementation of some of the annexes of the DPA undermined the ethno-national power that had been legitimised with the division of Bosnia in two entities. The Communist legacy and the power structures 
configured during the war provided these parties with the means of obstructing most international initiatives, having the fundamental interest in preventing structural reform of public institutions and the economy (ESI 1999). This resistance posed by local actors caused that the international civilian mission significantly evolved over time. In order to frame the difficulties of the path into the European integration, three distinct periods of international intervention are firstly analysed.

The first period was dominated by the prevalence of the military provisions of the DPA with a limited authority of the HR. If the DPA implied both military and civilian annexes, becoming a complex peace-building mission, during the early stages the military component was the main priority in order to fulfil the cease-fire and the demilitarisation. The United States played a central role that actually continued the one produced during the negotiations in Dayton to end the war. The transition of the international supervision to a self-governed democracy had to be completed in a short calendar of nine months after the celebration of first elections. Yet the international administration was prolonged successive times because of the lack of progresses in key areas of the civilian annexes.

In the prospect of gradual reduction of developing aid, the lack of collaboration and obstructionism from the ethno-national parties pushed the international community to reinforce its role to reinvigorate peace building and state building. In December 1997, the HR was thus empowered, becoming the final authority in the country after being granted with legislative and executive authority when local representatives did not achieve consensus or failed with implementation. With accusations of creating a protectorate, one of the most controversies was the right to dismiss local officials obstructing the DPA. These extraordinary measures, that could easily undermine the process of democratisation inherent to the peace-building mission, were conceived as temporary and exceptional.

Although there was will to replace the interventionist period for the empowerment of local institutions, the so-called Bonn Powers were increasingly used. Between 1997 and 1999 the HR Carlos Westendorp had an average of four impositions per month, while his successor, Wolfgang Petritsch, tripled the number of decisions. Both the nature and the evolution of the intervention have been questioned in the literature focused on the process of democratisation and peace building in Bosnia (CHANDLER 1999; KnAus \& MarTin 2003).

The capacity to legislate of the HR became a central tool for the international community to implement the DPA. However, with such capacity the HR began to impose laws that had never been either presented to a parliament or discussed with the responsible government, i.e. with no consensus with local politicians what complicated the subsequent enforcement. If Bonn Powers had proved essential for an early development of the constitutional order, laws required institutions to enforce them so the imposition was never sufficient per se (ESI 2000). This inefficiency in the powers used by the HR was also consequence of the architecture of international intervention adopted at Dayton, keeping a sharp separation between the military and the civilian 
aspects of the intervention while maintaining a very loose coordination among civilian agencies, which failed to provide the HR with strong political support. As BELLONI points out, this model would prove sufficient to preserve the absence of fighting but it was inadequate in addressing Bosnia's stateness problem (BELLONI 2007).

The third period of the international agenda started in March 2000 when the agenda for EU integration set the path to fulfil the Stabilisation and Association Process (SAP) from which the Stabilisation and Association Agreement (SAA) is part of it. It marked the rise of the European involvement in the country affecting the role of the OHR since it was increasingly shaped by EU strategies rather than by Dayton itself. The HR became double-headed as EU Special Representative and the EU enlargement process became a central tool to resolve Bosnia's main problems (CHANDLER 2005). It was not until 2008 when the SAA was signed, which should have opened a new phase in the integration process. Yet, for almost seven years it has not been ratified showing the complexity of the European integration process in post-war Bosnia and Herzegovina.

\section{The long and uncertain path to the ratification of the SAA}

The lack of ratification of the SAA since 2008 symbolises the structural difficulties to progress in the EU path. Before analysing the political regression produced in the country in the last years and the contradictions of the EU intervention in the country, it is important to consider the very signature of the SAA in order to highlight the often erratic strategy of European institutions in Bosnia, which has undermined its very legitimacy. In this sense, in late 2007 for the HR Miroslav Lajčák the progress on EU integration was the only way to get Bosnia out of the crisis. He suggested Oli Rehn, the European Commissioner for Enlargement, to consider acceptable the limited police reform to open the way for a Stabilisation and Association Agreement with Bosnia, despite the latest agreement fell short of complying with European conditionality. Thus, the HR's proposed approach seriously weakened the credibility of the EU in Bosnia since it had maintained for several years that any agreement on police reforms was needed to comply with the conditions (Leroux-Martin 2014). The decision to sign the SAA was in detriment of the European conditionality applied to the country as not all preconditions defended for years had been met. Its signature was used as a tool to leverage instead of being a consequence of the very progress of the country.

This lack of reforms had been evident well before the controversial signature of the SAA. Bosnia and Herzegovina needed a constitutional reform to further progress in the EU path since constitution vested powers to the two entities in which the country is divided. In order to implement the broad range of measures that the EU requires for 
the accession, which culminate with the adoption of the acquis communitaire, more competences had to be granted to the state. In this context, the so-called April Package in 2006 was the first attempt to reform the Constitution following the publication by the Venice Commission" in March 2005 of its "Opinion on the Constitutional Situation in Bosnia and Herzegovina and the Powers of the High Representative," known as the Venice Commission report. In the report it was warned that with the weak state structure of $\mathrm{BiH}$ the country would not be able to make progress towards the European integration. Hence, the subsequent negotiations marked the first time since the DPA that Bosnian political leaders discussed about the constitutional reform seriously (HAYs \& CROSBY 2006).

After months of negotiations the package of amendments represented consensus of five of the seven parties that began the process. Despite all the problematic issues pointed by the Venice Commission were not eliminated, the agreement represented a significant step forward since it supported the development of the state based on party lines instead of on entity or ethnic issues (HAYs \& CROSBY 2006). With a majority of twothirds required in the parliament the amendment failed only for two votes on 26 April 2006. As Sebastián (2010) argues in her analysis of the April Package, the fragmented nature of power in $\mathrm{BiH}$, both at inter-ethnic level and within each of ethnic groups, undermined the progress of the externally led state-building process. More specifically, the politics at the intra-ethnic level acquired a new dimension when the discussion entered in the Parliament in the last stage before the voting, which prevented reaching the majority required despite the consensus among the main ethno-national parties.

The failure of the April Package was not only a lost opportunity to advance in the necessary constitutional reforms in Bosnia to address the EU integration. Actually, as a consequence of the disagreement, parties against the package translated the debate about the issue of the constitutional reform in the October 2006 elections. It opened a period of regression marked by a highly nationalistic rhetoric in which the right of the Republika Srpska (RS) to celebrate a referendum emerged in the aftermath of the Montengro's referendum, justified by the alleged desire of Bosniaks to dominate the RS (see MAKSIC 2009; ToAl 2013). This political regression was not halted after the elections. In relation to the RS referendum discourse, it had another peak after the declaration of independence in Kosovo in February 2008. Furthermore, the contestation of state institutions was continuously reproduced afterwards and in May 2011 Catherine Ashton, the High Representative of the Union for Foreign Affairs and Security Policy, visited Banja Luka to persuade the president of Republika Srpska, Milorad Dodik, to postpone the organisation of a referendum on BiH's court and prosecutor's office (SMILJANIC 2011).

Another two attempts to reform the Constitution were produced after the failure of the April Package. The Prud negotiations were held from November 2008 until

With the name of the European Commission for Democracy through Law, the Commission is an advisory body of the Council of Europe composed of independent experts in the field of constitutional law. 
January 2009 with the participation of the three main political parties (SDA, SNSD and $\mathrm{HDZ} \mathrm{BiH}$ ). Parties agreed on fulfilling the five objectives and two conditions to close the $\mathrm{OHR}^{2}$, which was seen necessary to move forward with EU accession preparation. However, constitutional reform remained blocked, which showed the conflicting visions between the main Bosniak, Croat and Serbian parties (PERRY 2013). Finally, the Butmir conversations were celebrated in late 2009 in a joint EUUS initiative to break the long-standing political stalemate in $\mathrm{BiH}$ with the focus on constitutional reform and the conditions to close the Office of the High Representative. Despite Bosnian politicians had agreed that their country's goal was to join the EU and NATO (FENA 2009) and the proposal discussed was weaker than the April package, the Butmir Process collapsed after BiH's major political parties were unable to agree upon a platform for reform (PERRY 2013).

These three attempts can thus be differentiated. The April Package failed mainly because of intra-ethnic politics with divisions within the Croat and Bosniak communities. In the subsequent negotiations, however, the incompatible agendas at inter-ethnic level in an environment much more polarised prevented to reach an agreement in more basic forms of constitutional reform. Despite having highlighted the incapacity to make structural reforms by local actors, the failure in the European integration cannot be understood only internally, from the perspective of the lack of consensus about the vision of the state among main ethno-national parties.

Hence, considering the rise of the European role analysed in the previous section, it is important to point out the limits of the Europeisation in Bosnia and Herzegovina from the point of the international intervention. As Juncos (2012) argues, the EU's enlargement policy is actually undermined by a series of internal contradictions which are worth to focus on: The contradiction

(a) between the EU's technocratic approach adopted in the enlargement process and the politics of state building. Despite the enlargement is an inherently political process, the reforms are usually pushed through the basis of efficiency arguments, which have not always been accepted by local parties since the promotion of specific models of political and economic reorganisation touch upon core attributes of state sovereignty.

(b) between state-weakening and state-strengthening dynamics. In this sense, the process of central state building aimed at dealing with the membership obligations has been parallel to the Commission's recommendation of downsizing the public sector in Bosnia.

(c) between the external promotion of reforms and the notion of local ownership. Even if EU policies have not imposed in Bosnia due to the reluctance of the Commission

2 The five objectives were: an agreement on state property; an agreement of defense property; completion of the Brčko final award; fiscal sustainability; and entrenchment of the rule of law. The two conditions were a signed SAA and the Peace Implementation Council's (PIC) sign-off on full compliance with the Dayton Agreement. 
to use the Bonn Powers, the intensive intervention in the previous years had negative impact on the responsibility of the local authorities. Furthermore, EU has only been engaged with political elites while the EU integration has been perceived as the only viable option, with lack of alternatives.

(d) between EU member state-building policies and the goal of peace building. The goal of peace building is the elimination of the root causes of the conflict and the creation of the conditions for a sustainable peace while state building is a component of peace building with the focus on the creation and strengthening of legitimate state institutions. Member-state building has often clashed with peace building, being manifested in the problems of promoting reforms based on consensus. The lack of attention to fostering consensus building among ethnic groups necessary for a smoothly operation of state institutions has actually contributed to slowing down the pace of association and the integration into the EU.

In spite of the years of intervention and having achieved legislative and executive authority, international actors have achieved limited progress on the making of a functional state in post-war Bosnia. As a consequence, the reforms required to unblock the stalemate in the European path have been lowered from the initial constitutional reform aimed at preventing the blocking of the needed EU legislation. This process of lowering demands is well illustrated with the proposal, which will finally allow the ratification of the SAA after the so-called German-British Initiative launched in November 2014 by the German Foreign Minister Frank-Walter Steinmeier and Britain's Philip Hammond.

The constitutional reform was thus replaced as a condition to unblock the progress into the European path by a compromise of political forces to commit with the future EU perspective. The opened letter signed by the two Foreign Ministers asked the European Union to bring the SAA into force in case that the Bosnian politicians committed to a package of reforms closely linked to the Compact for Growth and Jobs that had been published a few months earlier, as response of the protests occurred in February 2014. Finally, on 23 February 2015, the Parliament adopted a key declaration pledging support to the country's EU accession process, opening the way for Brussels to activate Bosnia's Stabilisation and Association Agreement (JuKIC 2015).

\section{Conclusions}

The peace building and state building in post-war Bosnia have been complex processes with limited outcomes considering the personal and material resources invested in the country. The need to develop the civilian annexes of the DPA, quite ambiguous compared to the military provisions, and the role of ethno-national parties 
during the post-war period with diverse if not opposite agendas have posed major barriers in the development of a functioning state. In a parallel way, the policies set by the international actors have often produced unintended outcomes due to the poor adaptation to the needs and complexity of Bosnia and Herzegovina, and even a lack of comprehension of the reality on the ground.

In the last few weeks a new road map proposed by Foreign Ministers of Germany and Britain has been brought to unblock the ratification of the SAA. It has been consequence of a new formula, which aims at producing the reforms in the following years after the compromise of the political parties. The new road map has been endorsed by the Parliament as these lines are being written. We will have to see whether or not it will generate any changes in both the poor implementation and the lack of consensus among main political parties characteristic of the post-war period. What is clear is that after several unsuccessful attempts to produce a significant constitutional reform needed to face the challenges of the European integration, lowering the requirements to resume the European path might only produce an illusion of progress as the one generated after the signature of the SAA in 2008.

\section{References}

Belloni R. (2007), State Building and International Intervention in Bosnia. London, Routledge.

Chandler D. (1999), Bosnia: Faking Democracy After Dayton. London, Pluto Press.

Chandere D. (2005), From Dayton to Europe. In: International Peacekeeping, 12, 3, pp. 336349.

DonaIs T. (2005), The Political Economy of peacebuilding in Post-Dayton Bosnia. London New York, Routledge.

ESI (1999), Reshaping international priorities in Bosnia and Herzegovina. European Stability Initiative, 14 October 1999.

ESI (2000), Reshaping international priorities in Bosnia and Herzegovina. European Stability Initiative, 30 March 2000.

FENA (2009), Inzko: International community will prevent any conflict in BiH, In: FENA, 29/10/2009.

Hays D., Crosby J. (2006), From Dayton to Brussels Constitutional Preparations for Bosnia's EU Accession (= USIP Special Report, 175). Washington DC, United States Institute of Peace.

Jukic E. (2015), Bosnian Lawmakers Unblock Path Towards EU. In: BIRN, 23/02/15.

Jucos A.E. (2012), Member state-building versus peacebuilding: the contradictions of EU statebuilding in Bosnia and Herzegovina. In: East European Politics, 28, 1, pp. 58-75.

Knaus G., Martin F (2003), Travails of the European Raj. In: Journal of Democracy, 14, 3, pp. 60-75. 
Leroux-Martin P. (2013), Diplomatic Counterinsurgency: Lessons from Bosnia and Herzegovina. Cambridge, Cambridge University Press.

Maksic A. (2009), Referendum Discourse in Republic of Srpska Politics 2006-2008: An Analysis of its Emergence and Performative Structure. Alexandria (Virginia), MA thesis, not published.

Perry V. (2015), Not-So-Great Expectations: The EU and the Constitutional Politics of Bosnia and Herzegovina. In: KeIL S., Arkan Z. (eds.), The EU and Member State Building, pp. 163-188. New York, Routledge.

Sebastián S. (2010), Statebuilding in Divided Societies: The Reform of Dayton in Bosnia and Herzegovina. In: Journal of Intervention and Statebuilding, 4, 3, pp. 323-344.

SMILJANIC L. (2011), Dodik cancels referendum after talks with Ashton. In: Southeast European Times for Banja Luka, 16/05/2011.

ToAL G. (2013), Republika Srpska Will Have a Referendum: The Rhetorical Politics of Milorad Dodik. In: Nationalities Papers, 41, 1, pp. 166-204. 